\title{
Flooded flatheads: evidence of increased growth in Mississippi River Pylodictis olivaris (Pisces: Ictaluridae) following the Great Midwest Flood of 1993
}

\author{
Brian D. Jones · Douglas B. Noltie
}

Published online: 21 September 2007

(C) Springer Science+Business Media B.V. 2007

Erratum to: Hydrobiologia (2007) 592:183-209

DOI 10.1007/s10750-007-0744-0

Please note the following amendments to this article:

Figure 5: each diagram should be rotated $90^{\circ}$ anticlockwise, thus:

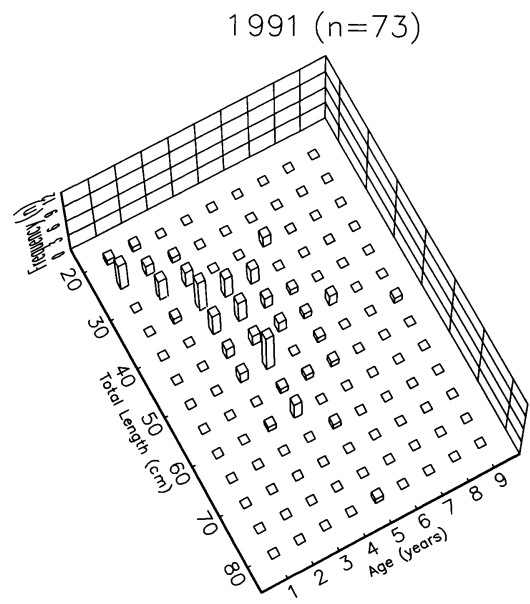

The online version of the original article can be found under doi: 10.1007/s10750-007-0744-0.

B. D. Jones · D. B. Noltie $(\square)$

Department of Fisheries and Wildlife Sciences, The School of Natural Resources, University of Missouri-Columbia, 302 Anheuser-Busch Natural Resources Building, Columbia, MO 65211-7240, USA

e-mail: NoltieD@missouri.edu
Tables 1 and 2: the heading of column 3 should read 'Total \# of fish'. Line 3 of the footnotes should also read 'Total \# of fish'.

Table 3: the headings of columns 2 and 3 should read 'Year' and 'Value'.

Table 4: the heading of column 4 should read 'Total \# of fish'.

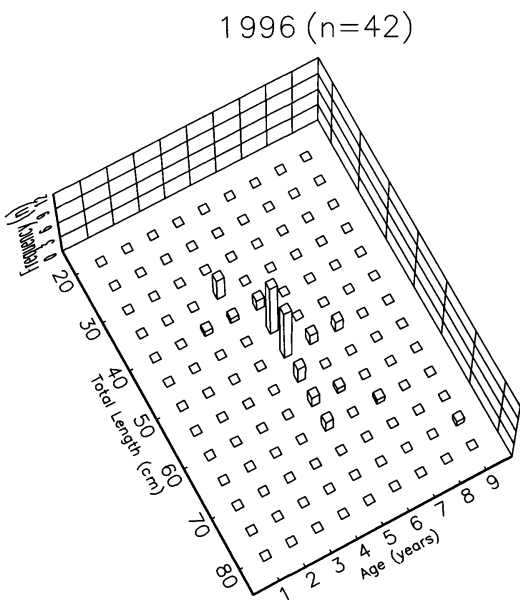

